\title{
FORMATION AND EVALUATION OF ANTI-CORRUPTION LEGAL AWARENESS STUDENTS
}

\begin{abstract}
Аннотация. B статье обоснована актуальность темы антикоррупичонного просвещения молодежи, приведены результаты исследования антикоррупционного правосознания обучаюшихся на базе ФГБОУ ВО «Ангарский государственный технический университет», сделаны выводы о необходимости разработки комплекса мер, направленных на усиление восприятия коррупции как негативного соцчильного явления студенческой молодежью.

Ключевые слова: коррупичя, правосознание, антикоррупционное образование, антикоррупционное просвещуение.

Abstract. The article substantiates the relevance of the topic of anti-corruption education of youth, presents the results of a study of the anti-corruption legal awareness of students on the basis of the Angarsk State Technical University, concludes that it is necessary to develop a set of measures aimed at strengthening the perception of corruption as a negative social phenomenon by student youth.
\end{abstract}

Keywords: corruption, legal awareness, anti-corruption education, anti-corruption education.

Коррупция - явление повсеместное, давнее и известное каждому. Являясь социальной категорией, а также и экономической, коррупция отражает не только незаконную деятельность всех должностных лиц, но и является индикатором уровня правовой культуры граждан, степени стабильности политической ситуации в стране, эффективности взаимодействия в целом государства и социума.

Борьба с коррупцией в последние годы вошла в число приоритетных задач Российской Федерации. Органы власти страны однозначно заявили о необходимости всем институтам гражданского общества способствовать реализации государственной антикоррупционной политики. Высшие учебные заведения, в данной связи, могут активизировать антикоррупционное воспитание молодежи, сформировать или закрепить основы антикоррупционного правосознания, лежащего в русле проводимой государственной политики, направленной на усиление в обществе нетерпимости к коррупционному поведению.

Тезис о необходимости развертывания системы гражданского просвещения, включающей обучение антикоррупционному поведению, прозвучал в послании Президента
РФ Федеральному Собранию в 1998 году, но задача по активации просветительской деятельности впервые была поставлена перед органами государственной власти и местного самоуправления только в рамках Национального плана противодействия коррупции на 2014-2015 годы [1].

Возрастающая актуальность проблемы антикоррупционного просвещения молодежи подтверждается многочисленными мероприятиями и публикациями. Так, ежегодно проводится Евразийский антикоррупционный форум, на котором осуществляется обмен актуальными знаниями и опытом в сфере противодействия коррупции, в том числе среди молодежи [2]. В марте 2020 года в Казани состоялся Всероссийский молодежный антикоррупционный форум, итогами которого стало определение лучших региональных практик работы с молодёжью в антикоррупционном направлении, выработка приоритетных направлений в сфере профилактики коррупции в молодёжной среде [3].

Акунченко Е.А. отмечает, что антикоррупционное просвещение является новым инструментом социального управления, назначение которого заключается в формировании в обществе нетерпимости к коррупционному поведению [4]. Мешкова Н.Д. указы- 
вает на значимость антикоррупционного просвещения среди всех инструментов, способствующих удержанию коррупции на социально терпимом уровне. В частности, к ним относятся: антикоррупционное просвещение, антикоррупционное информирование, антикоррупционное консультирование, антикоррупционное образование, антикоррупционная реклама и антикоррупционная пропаганда [5].

Из резолюции по итогам Всероссийского антикоррупционного форума с международным участием «МАФ-2020», проведенного в г. Саранске 20 ноября 2020 г., следует, что необходимо усиление мер, направленных на антикоррупционное обучение и воспитание молодежи [6].

О роли антикоррупционного просвещения и его значении в минимизации уровня коррупции указывает Руева Е.О., подчеркивая, что «отличием современной молодежи является высокий уровень деформации собственного правосознания, поэтому любые проявления коррупции представляются чемто привычным и обыденным». Следовательно, остро назрела необходимость формирования антикоррупционного правосознания молодежи [7].

Одной из таких мер стало включение в федеральные образовательные стандарты многих направлений подготовки положения о формировании обязательной антикоррупционной компетенции выпускника. В связи с этим, в ФГБОУ ВО «Ангарский государственный технический университет» формирование данной компетенции осуществляется посредством введения лекционных и практических занятий по теме антикоррупционной направленности по ряду дисциплин. Ранее тема коррупции, ее видов и борьбы с нею изучалась в рамках темы уголовной ответственности по дисциплине «Правоведение», в настоящее время требуется более детальный подход к изучению данного вопроса: увеличение количества часов, разработка лекционных курсов и методических материалов к проведению практических занятий, разработка неформальных способов антикоррупционного воспитания студентов.

Для оценки «входного» уровня восприятия студенческой молодежью коррупции, как негативного социального явления, и выявления начального уровня знаний среди обучающихся университета был проведен социальный опрос. Целевую аудиторию со- ставили студенты очной формы обучения второго, третьего и четвёртого курсов обучения в количестве 70 человек. Средний возраст опрашиваемых - 20 лет.

Проведение такого рода исследований является действенным инструментом для определения уровня знаний о данном явлении, отслеживания отношения студентов к коррупции и разработки либо корректировки плана мероприятий по антикоррупционному воспитанию студенческой молодежи.

В ходе анонимного исследования респондентам было предложено 10 вопросов. Первым из них было предложено определить, что они понимают под словом «коррупция». Подавляющее большинство студентов (98\% от числа опрошенных) определили коррупцию как «взяточничество» и «злоупотребление служебными полномочиями». При этом однократно среди прочих вариантов прозвучал вариант «кража». Один студент выбрал вариант определения коррупции, как подношение подарков должностным лицам. Таким образом, отмечается цельность в понимании сущности явления коррупция.

Абсолютное большинство респондентов (98\%) сошлись во мнении, что «коррупция сильно влияет на экономику страны». Один студент затруднился ответить на этот вопрос.

Отвечая на вопрос об оценке уровня коррупции в различных сферах, было предложено распределить профессии (сферы деятельности) по степени коррумпированности в соответствии с системой личного отношения опрашиваемого. Самой коррумпированной оказались работники органов власти (чиновники). Следующими явились сотрудники ГИБДД и судебная система. Далее идут сотрудники полиции, работники ВУЗов и сотрудники таможенных органов. Менее коррумпированными студенты считают такие сферы, как область ЖКХ и земельных отношений, гимназии и средние общеобразовательные школы, медицину. Многие (52\%) определили систему организации устройства детей в детские сады, как самую некоррумпированную сферу.

Среди причин, порождающих коррупцию, наиболее часто встречались такие варианты, как: недостаток контроля, эксплуатация «дружеских связей», недостаточные меры ответственности; незнание или непонимание законов населением, что позволяет должностным лицам произвольно препятст- 
вовать осуществлению бюрократических процедур, традиция дарения «взяток - подарков». Этим вопросом было определено, как молодежь воспринимает само явление коррупции и что считает первопричиной таких действий.

Оценивая степень важности последствий коррупции, 61\% опрашиваемых отметили снижение доверия общества к власти, разочарование в ценностях демократии; 51\% назвали главным последствием коррупции нарушение прав человека; 39\% выделили среди последствий потерю доверия граждан к государственной системе и, как следствие, рост правового нигилизма в обществе.

Наиболее эффективными мерами борьбы с коррупцией опрошенные посчитали ужесточение наказания за коррупцию и лишение должностей на длительный срок. Один студент выразил мнение, что никакие меры не помогут. Двое выразили мнение, что повышение уровня правовой культуры граждан может помочь в борьбе с коррупцией. Такие варианты, как пропаганда нетерпимости коррупции и предоставление услуг в электронном виде, были поддержаны $15 \%$ опрошенных.

Более 75\% респондентов предпочтут сообщить о факте коррупции, но анонимно, 4 $\%$ проинформируют открыто и пятая часть опрошенных (20\%) не собираются заявлять о фактах коррупции. При этом, на вопрос о личном отношении к коррупции, 70\% студентов выразили отрицательное отношение, $27 \%$ указали на нейтральное отношение и $3 \%$ указали на положительное отношение к коррупции.

Анализируя ответы на вопрос: «В каких случаях все-таки допустимо предложить взятку за решение Вашего вопроса?», было выявлено, что 3 \% респондентов ответили, что если это незаконное действие позволит ускорить решение вопроса, то они его допускают; 7\% студентов указали, что если сумма вознаграждения за услуги будет разумной, то они пойдут на нарушение закона для решения своего вопроса. Остальные 90\% указали на недопустимость взятки при любых обстоятельствах.

На вопрос о том, кто несет большую ответственность в случаях взяточничества, только $65 \%$ ответили, что виновны обе стороны, 35\% считают, что закон нарушает только одна сторона - тот, кто берет взятки.

Таким образом, результаты опроса показали следующее:

- студенты владеют верным представлением о понятии коррупции, могут определить причины и негативные последствия данного явления;

- выявлены пробелы в знаниях о мерах ответственности за совершение коррупционных правонарушений, в частности в области ответственности всех участников коррупционного правонарушения;

- сделан вывод о необходимости корректировки антикоррупционного образования молодежи, т.к. около трети студентов выразили нейтральное, а значит равнодушное отношение к коррупции.

С учетом полученных результатов социального опроса представляется целесообразным продолжить и усилить комплекс мероприятий, проводимых университетом, направленных на правовое антикоррупционное просвещение студенческой молодежи, формирование негативного отношения к коррупции, нулевой терпимости к данному социальному явлению.

\section{СПИСОК ЛИТЕРАТУРЫ}

1. О Национальном плане противодействия коррупции на 2014-2015 годы: указ Президента РФ от 11.04.2014 № 226. - Текст: непосредственный // Собрание законодательства РФ. 2014. № 15. СТ. 1729.

2. Ежегодный евразийский антикоррупционный форум. - Текст: электронный // Институт законодательства и сравнительного правоведения при правительстве РФ. - URL: https://izak.ru/conferences/ezhegodnyy-evraziy skiy -antikorruptsionnyy-forum (дата обращения: 11.11.2021).
3. Всероссийский молодежный антикоррупционный форум. - Текст: электронный // Росмолодежь. - URL: https://myrosmol. ru /measures/view/40467 (дата обращения 11.11.2021).

4. Акунченко Е.А. Антикоррупционное просвещение в системе предупреждения коррупции. - Текст: непосредственный // Сб. науч. ст. по материалам II Сибирского антикоррупционного форума «Актуальные проблемы антикоррупционного просвещения и антикоррупционного образования», Красно- 